\title{
Memories of John L. Fahey, M.D.'s Clinical Immunology Society Years
}

\author{
Susan Kanowith-Klein \\ 1331 Avenida de Cortez, Pacific Palisades, CA 90272; Tel.: 310-459-9443; Fax: 310-459-9443; E-mail: skklein@ucla.edu
}

\begin{abstract}
John L. Fahey, M.D. headed a team of researchers, clinicians, and other academic staff throughout his career at the University of California, Los Angeles, working with them in various capacities. Here, I recount my memories of working with Dr. Fahey during the early years of the Clinical Immunology Society.
\end{abstract}

KEY WORDS: Clinical Immunology Society, John Fahey

ABBREVIATIONS: CIS: Clinical Immunology Society

\section{PERSPECTIVES}

In the early months of 1986, Dr. John L. Fahey invited me to assist him and other immunologists from across the country to create a national organization devoted to the advancement of the field of clinical immunology. Because it was best to say "yes" to Dr. Fahey, I readily agreed and became involved in establishing the Clinical Immunology Society (CIS). Dr. Fahey once described our task as working "on the one hand with rather wild and woolly characters and on the other, with super conservative traditionalists"!

At first, my responsibilities were to raise funds for CIS and its annual conferences from pharmaceutical and biotechnology companies and nonprofit organizations; maintain communication with the National Institute of Allergy and Infectious Diseases, American Association of Immunologists, and other professional groups; and coordinate conference arrangements. However, with Dr. Fahey's encouragement, my position evolved into developing CIS goals, bylaws, the council and its governance, committees and their tasks, membership, and, in general, getting mechanisms in place for CIS's continuity and growth. Dr. Fahey chronicles this time in some detail " in "Clinical Immunology Society: The Early Years 1984-1985."

It was typical of Dr. Fahey to offer both researchers and clinicians suggestions leading to career oppor-

\footnotetext{
*http://www.clinimmsoc.org/about-cis/history-of-cis.
}

tunities. (See other articles in this journal.) Simply put, Dr. Fahey provided various avenues for others to pursue. Personally, his offer to me to work with him on CIS was a great new direction for me. Although a part-time position initially, responsibilities grew and presented important learning experiences and farreaching implications for my future career.

During the first years of establishing CIS and then while Dr. Fahey served as its first president, he and I met weekly, at our scheduled time and sometimes in between, depending on what was happening. Dr. Fahey worked in one-hour increments, and I always ran out of time when we met although I arrived at his office with an agenda and usually some text to review and discuss (letters for approval, drafts regarding any number of items). I was ready to dive right in, but Dr. Fahey ensured always with a glint in his eye that first there were pleasantries: maybe some humorous referral to the three Susans with whom he worked and who kept him busy, maybe an offer of chocolate, or maybe news of his latest travels.

Often, we would sit side-by-side as he reviewed the material. He would add comments in his scrawllike handwriting to what I had written. I felt I was in the "hot seat" yet ready to defend my suggestions. One could know immediately what he was thinking: He would discuss ideas that he thought were worthwhile but pass over (i.e., completely ignore) those that he did not like. This was Dr. Fahey's way of pointing me in the direction he chose to pursue. 
On the other hand, although he might make specific decisions perhaps in haste, he was willing to revisit those decisions once he reflected on and understood opposing views. Once we exchanged heated words, and I went off to sulk. But just minutes later, Dr. Fahey came to me, apologized, and admitted that I had been right. Not liking an idea or a viewpoint at first could stir his keen insights, prompting him to give it another look.

Dr. Fahey frequently worked at his home in the early morning. Occasionally, when his car was being serviced, he would ask me to pick him up on my way to campus. This request was code for "come to my house, sit with me at the dining room table covered with piles of paper arranged according to topic, and go over some CIS work." This meeting time was good; no one would disturb us and the meeting could last more than an hour.

I always admired the way Dr. Fahey was able to bring together people of completely opposing views on a subject-perhaps immunologists with opinions - and get them to put aside previous judgments and have a reasonable discussion. To do so, he frequently used a phrase such as "Let's explore the idea of. ..." Using this terminology, specifically, the word "explore," he was able to diffuse sharply divided views and turn individuals around to consider a particular way of thinking. I called this fine-tuned skill "Fahey finesse." He was great at it!

In his leadership role, Dr. Fahey was faithful to CIS colleagues and the CIS professional staff by freely acknowledging and thanking them for their contributions. Although he might be stubborn at times, he was a generous and kind man. I will always appreciate the letters he wrote with positive comments about my performance and the manner in which he included my involvement in his history of "Clinical Immunology Society: The Early Years 1984-1985".

As many know, Dr. Fahey loved parties and tried not to miss a one. I was so honored when years after we had formally worked together, he came to my University of California, Los Angeles (UCLA) retirement party and spoke to those gathered about the time he and I devoted to CIS. He was loyal and genuinely cared for "his team."

\section{ACKNOWLEDGMENTS}

I thank Susan Stehn, M.S. and Ms. Ginny King Supple for helpful discussions, recollections, and assistance in preparing this article. 